\section{pH Affects Seed Germination of Eight Bedding Plant Species}

\author{
Candice A. Shoemaker' and William H. Carlson ${ }^{2}$ \\ Department of Horticulture, Michigan State University, East Lansing, \\ MI 48824
}

\begin{abstract}
Additional index words. annuals, acidity, Ageratum houstonianum, Lobularia manritima, Begonia $\times$ semperflorens, Pelargonium hortorum, Impatiens wallerana, Tagetes patula, Petunia $\times$ hybrida, Salvia splendens
\end{abstract}

\begin{abstract}
Seeds of eight commonly grown bedding plant species [Ageratum houstonianum Mill., Begonia $\times$ semperflorens Hort., Impatiens wallerana Hook., Lobularia maritima (L.) Desv., Petunia $\times$ hybrida Hort., Pelargonium hortorum L.H. Bailey, Salvia splendens F. Sellow, Tagetes patula] were germinated at $\mathrm{pH}$ values from 4.5 to 7.5 at 0.5 increments. Seeds were germinated in petri dishes on filter paper saturated with buffer solutions or in petri dishes containing a 50 sphagnum peat: 50 coarse vermiculite (peatlite) medium moistened with buffer solutions. Germination on filter paper was affected by $\mathrm{pH}$ for all species tested. Peatlite medium $\mathrm{pH}$ affected germination of all species tested, except Salvia splendens. Species response to similar pH values differed between the two germination procedures. Total percent germination of seeds germinated was less in peatlite medium than on filter paper.
\end{abstract}

The influence of hydrogen ion concentration $(\mathrm{pH})$ on germination has received little attention in horticulture. Most information reported on the effects of $\mathrm{pH}$ on germination is for field crops, weed seeds, conifers, and broad-leaved trees. $\mathrm{pH}$ values lower than 3 and higher than 8 have been reported to inhibit germination (Jansen and Cronin, 1953; Malhotra, 1930; Salter and McIlvaine, 1920), while other reports suggest that germination of many species is unaffected by $\mathrm{pH} 3$ to 7 (Chan, 1937; Schmidt, 1927). An optimum $\mathrm{pH}$ is reported for some species (Jansen and Cronin, 1953; Malhotra, 1930; Peel, 1949).

An optimum $\mathrm{pH}$ of 6.0 is reported for sunflower (Helianthus annus) and tomato (Lycopersicon esculentum) when germinated between layers of filter paper in petri dishes (Malhotra, 1930; Peel, 1949). Germination of tomato and petunia (Petunia $\times$ hybrids) was not affected when seeds were irrigated with water at various acidities (Bailey and Hammer, 1986). Heather (Calluna vulgaris) germinated best at $\mathrm{pH} 4.0$ on an agar medium containing Knop's solution (Peel, 1949). A slightly acidic condition favored germination of several forage crops (Promsy, 191 1). Alfalfa, corn, red clover, soybeans, and wheat seeds placed on filter paper in petri dishes showed no statistical differences in germination for $\mathrm{pH} 3$ through 8 , although a slightly

Received for publication 12 Dec. 1988. Michigan Agr. Expt. Sta. J. Article no. 12920. This study was partially funded with a grant from the Western Michigan Bedding Plant Growers Assn. We express our appreciation to the Ball Seed Co. for the donation of seed. The cost of publishing this paper was defrayed in part by the payment of page charges. Under postal regulations, this paper therefore must be hereby marked advertisement solely to indicate this fact.

'Research Associate. Current address: Dept. of Horticulture, Virginia Polytechnic Inst. \& State Univ., Blacksburg, VA 24061-0327.

${ }^{2}$ Professor. acid condition tended to be favorable (Salter and McIlvaine, 1920).

A growth medium $\mathrm{pH}$ of 5.5 to 7.0 is recommended for producing bedding plants (Carlson and Rowley, 1980). The optimum $\mathrm{pH}$ for bedding plant seed germination is not known, although a pH of 5.2 to 6.0 is recommended (Koranski, 1985). The small volume of growth medium used in plug production can cause wide fluctuations in moisture content, aeration, soluble salt levels, nutrient levels, and pH (Koranski, 1985). The objective of this study was to determine if an optimum $\mathrm{pH}$ range exists for the germination of eight plant species commonly grown as bedding plants.

Species and cultivars tested were: $A$. houstonianum 'Adriatic' (ageratum), $B$. $\times$ semperflorens 'Scarlanda' (begonia), L wallerana 'Fantasia Red' (impatient), $L$. maritima 'New Carpet of Snow' (alyssum), P. $\times$ hybrida 'Old Glory Red' (petunia), $P$. hortorum 'Red Elite' (seed geranium), S. splendens 'Red Hot Sally' (salvia), and $T$. patula 'Queen Sophia' (marigold).

Experiments with two germination media were conducted twice in reach-in controlledenvironment growth chambers that were maintained day and night at $24 \mathrm{C}$ with continuous irradiance. Photosynthetic photon flux (PPF) was $50 \mu \mathrm{mol} \cdot \mathrm{s}^{-1} \cdot \mathrm{m}^{-2}$ provided by coolwhite flourescent lamps. PPF was measured with a LI-COR LI-185B meter and LI-190SB quantum sensor (LI-COR, Lincoln, Neb.).

Filter paper as medium. Seeds were germinated in $100 \times 15-\mathrm{mm}$ petri dishes on saturated filter paper at $\mathrm{pH} 4.5$ to 7.5 in 0.5 increments. Buffered $\mathrm{pH}$ solutions $(1 \mathrm{ml})$ containing potassium phosphate $(0.2 \mathrm{M})$ and calcium phosphate $(0.2 \mathrm{M}$ or $0.1 \mathrm{M})$ were applied daily to maintain saturation.

One hundred seeds were used per petri dish for each species, except $T$. patula, for which we used 50. The experiment was conducted twice, with three samples per treat- ment each time it was conducted. The experiment was established using a randomized block design.

Peatlite as medium. Seeds were germinated in $100 \times 15$-mm petri dishes containing a 50 sphagnum peat : 50 coarse vermiculite medium (peatlite) (v/v). Four-liter aliquots of medium were adjusted to the various $\mathrm{pH}$ levels by adding up to $200 \mathrm{~g}$ calcium carbonate. After the calcium carbonate was added, the $\mathrm{pH}$ was monitored to determine when the reaction stabilized. The $\mathrm{pH}$ was determined with a 1 medium : 1 distilled water mixture (v/v). After $48 \mathrm{hr}$, three consecutive $\mathrm{pH}$ measurements of similar readings indicated the reaction had stabilized and the experiments were initiated. Each petri dish contained $200 \mathrm{ml}$ of medium. Medium $\mathrm{pH}$ was within \pm 0.2 increments of their desired level at the beginning of the experiment. The $\mathrm{pH}$ of each petri dish was determined at the conclusion of the experiment. Medium $\mathrm{pH}$ was within \pm 0.1 unit of the desired level at the conclusion of the experiment, except the target $\mathrm{pH} 5.5$ medium, where actual $\mathrm{pH}$ was 5.9. The results from this treatment were excluded from analysis.

At the onset of the experiment, $4 \mathrm{ml}$ of deionized water was applied to the medium in each petri dish. Subsequent waterings were made by using $2 \mathrm{ml}$ of solution buffered at the respective $\mathrm{pH}$ levels. Ten seeds were placed, uncovered, in each petri dish for each species. The experiment was conducted twice, with three samples per treatment each time, for a total of 60 seeds per species. The experiment was established using a randomized block design.

Germination was counted when the cotyledons were fully expanded. Number of seeds germinated was recorded 5 days after sowing for ageratum, 8 days for marigold, 12 days for petunia and seed geranium, 14 days for alyssum, 18 days for impatiens, and 21 days for begonia and salvia. Observation of daily counts of germinated seeds on filter paper indicated that germination was not delayed by $\mathrm{pH}$ in the range evaluated, so analysis was conducted using final percent germination.

Data were transformed using arcsin transformation and then subjected to analysis of variance and trend analysis. Low $(<20 \%)$ or no germination was found in the following treatments: $\mathrm{pH} 4.5$ and 5.0 for ageratum, begonia, alyssum, petunia, salvia, and marigold; $\mathrm{pH} 4.5$ to 5.5 for impatiens; $\mathrm{pH} 4.5$ for seed geranium placed on filter paper; and $\mathrm{pH} 4.5$ for petunia and impatiens on peatlite. Trend analysis excluded data from these treatments to remove bias.

Filter paper. Germination on saturated filter paper was dramatically affected by $\mathrm{pH}$ for all species tested (Table 1). Begonia, impatiens, alyssum, petunia, and salvia did not germinate at or below $\mathrm{pH}$ 5.0. Germination was very low for ageratum and marigold in this range.

In the range where germination did occur, it was linearly related to $\mathrm{pH}$ for all species evaluated, except begonia and marigold (Table 1). For ageratum, begonia, impatiens, 
Table 1. Final percent germination of eight bedding plant species as affected by $\mathrm{pH}$.

\begin{tabular}{|c|c|c|c|c|c|c|c|c|c|c|}
\hline \multirow[b]{3}{*}{ Species } & \multirow{3}{*}{$\begin{array}{c}\text { Germi- } \\
\text { nation } \\
\text { test }^{\mathbf{z}}\end{array}$} & \multicolumn{8}{|c|}{ Germination (\%) } & \multirow{3}{*}{$\begin{array}{c}F \\
\text { value }\end{array}$} \\
\hline & & \multirow[b]{2}{*}{ Experiment } & \multicolumn{7}{|c|}{$\mathrm{pH}$} & \\
\hline & & & 4.5 & 5.0 & 5.5 & 6.0 & 6.5 & 7.0 & 7.5 & \\
\hline & 91 & Filter paper & 1 & 1 & 62 & 86 & 88 & 92 & 89 & $70.69^{* * *}$ \\
\hline & & & & & & & & & & $\begin{array}{lc}\mathrm{L} & 11.25^{* * *} \\
\mathrm{Q} & 5.75^{* * *}\end{array}$ \\
\hline & & Peatlite & 87 & 60 & y & 77 & $\cdot 67$ & 57 & 60 & $2.31^{* *}$ \\
\hline & & & & & & & & & & $\begin{array}{ll}\text { L } & 6.61^{* *} \\
\text { Q } & 0.00\end{array}$ \\
\hline \multirow[t]{4}{*}{ Begonia $\times$ semperflorens } & 75 & Filter paper & 0 & 0 & 87 & 94 & 84 & 92 & 87 & $59.48^{* * *}$ \\
\hline & & & & & & & & & & $\begin{array}{ll}\mathrm{L} & 1.98 \\
\mathrm{O} & 1.79\end{array}$ \\
\hline & & Peatlite & 80 & 87 & y & 80 & 87 & $77^{\circ}$ & 87 & $4.85^{* *}$ \\
\hline & & & & & & & & & & $\begin{array}{ll}\mathrm{L} & 11.39^{* *} \\
\mathrm{O} & 7.75^{*}\end{array}$ \\
\hline \multirow{4}{*}{ Impatiens wallerana } & 96 & Filter paper & 0 & 0 & 7 & 80 & 87 & 93 & 92 & $107.09^{* * *}$ \\
\hline & & & & & & & & & & $\begin{array}{ll}\mathrm{L} & 6.05^{*} \\
\mathrm{Q} & 0.82\end{array}$ \\
\hline & & Peatlite & 0 & 60 & y & 90 & 80 & 83 & 87 & $10.08^{* * *}$ \\
\hline & & & & & & & & & & $\begin{array}{lc}\mathrm{L} & 2.06 \\
\mathrm{Q} & 36.44^{* * *}\end{array}$ \\
\hline \multirow[t]{4}{*}{ Lobularia maritima } & 80 & Filter paper & 0 & 0 & 53 & 69 & 72 & 77 & 73 & $515.87^{* * *}$ \\
\hline & & & & & & & & & & $\begin{array}{ll}\mathrm{L} & 38.61^{* * *} \\
\mathrm{Q} & 16.58^{* * * *}\end{array}$ \\
\hline & & Peatlite & 50 & 47 & $y$ & 60 & 60 & 47 & 63 & $6.94 * * *$ \\
\hline & . & & . & & & & & & & $\begin{array}{ll}\text { L } & 19.04^{* *} \\
\mathrm{O} & 10.26^{* *}\end{array}$ \\
\hline \multirow{4}{*}{ Petunia $\times$ hybrida } & 88 & Filter paper & 0 & 0 & 77 & 87 & 83 & 83 & 86 & $562.92^{* * *}$ \\
\hline & & & & & & & & & & $\begin{array}{ll}\mathrm{L} & 4.88^{* *} \\
\mathrm{O} & 1.19\end{array}$ \\
\hline & & Peatlite & 33 & 80 & $y$ & 80 & 87 & 80 & 93 & $2.50^{* *}$ \\
\hline & & & & & & & & & & $\begin{array}{lc}\mathrm{L} & 0.84 \\
\mathrm{O} & 93.24^{* * *}\end{array}$ \\
\hline \multirow{4}{*}{ Pelargonium hortorum } & 88 & Filter paper & 3 & 89 & 90 & 94 & 91 & 93 & 93 & $113.76^{* * *}$ \\
\hline & & & & & & & & & & $\begin{array}{ll}\mathrm{L} & 2.79^{*} \\
\mathrm{O} & 0.64\end{array}$ \\
\hline & & Peatlite & 37 & -43 & y & 77 & $x$ & 77 & 83 & $25.88^{* * *}$ \\
\hline & & & & & & & & & & $\begin{array}{ll}\text { L } & 77.16^{* * * *} \\
\text { Q } & 3.90\end{array}$ \\
\hline \multirow[t]{4}{*}{ Salvia splendens } & 75 & Filter paper & 0 & 0 & 44 & 64 & 72 & 70 & 70 & $314.34^{* * *}$ \\
\hline & & & & & & & & & & $\begin{array}{ll}\text { L } & 37.87^{* * *} \\
\text { Q } & 20.76^{* * *}\end{array}$ \\
\hline & & Peatlite & 67 & 67 & y & 77 & 83 & 60 & 77 & $1.68^{\mathrm{NS}}$ \\
\hline & & & & & & & & & & $\begin{array}{ll}\mathrm{L} & 1.88 \\
\mathrm{O} & 1.34\end{array}$ \\
\hline \multirow[t]{5}{*}{ Tagetes patula } & $x$ & Filter paper & 17 & 20 & 80 & 86 & 86 & 84 & 87 & $23.02^{* * *}$ \\
\hline & & & & & & & & & & $\begin{array}{ll}\mathrm{L} & 0.88 \\
\mathrm{O} & 0.13\end{array}$ \\
\hline & & Peatlite & 60 & 63 & $y$ & 40 & 83 & 83 & 93 & $8.38^{* * *}$ \\
\hline & & & & & & & & & & L $39.10^{* * *}$ \\
\hline & & & & & & & & & & $\begin{array}{ll}\text { Q } & 0.19\end{array}$ \\
\hline
\end{tabular}

${ }^{2}$ Germination test is percent germination provided by seed supplier.

'The results from the peatlite experiment for PH 5.5 were excluded from analysis due to the +0.4 unit increase in PH during the experiment.

${ }^{\times}$Missing data.

NS,*,******Nonsignificant or significant at $P=0.01,0.05$, or 0.001 , respectively, for the main effect of $\mathrm{pH}$.

alyssum, and petunia, germination increased as $\mathrm{pH}$ increased from 5.0 to 6.0. For marigold, geranium, and salvia, response was similar, although the exact $\mathrm{pH}$ range for increased germination varied: 4.5 to 6.0 for marigold, 4.5 to 5.5 for geranium, and 5.0 to 6.5 for salvia.

Peatlite. Peatlite medium $\mathrm{pH}$ did not influence germination of salvia (Table 1). While five species did not germinate on saturated filter paper at $\mathrm{pH} 5.0$ and below, all but impatiens germinated on peatlite medium at $\mathrm{pH}$ 4.5.

Changes in germination at the $\mathrm{pH}$ levels species was nonlinear across the entire $\mathrm{pH}$ range on filter paper, but nonlinearity was true only for impatiens and petunia on the peatlite medium.

Percent germination between $\mathrm{pH} 5.0$ to 6.0 shifted for all species evaluated when germinated on filter paper (Table 1). This shift in percent germination is also evident for most of the species when germinated on the peatlite medium, although the trend is not as dramatic. These results confirm the recommended $\mathrm{pH}$ range of 5.2 to 6.0 for bedding plant seed germination (Koranski, 1985).

Since standard germination procedures (Hunter et al., 1984) were followed in the filter paper experiment, experimental results should be comparable with the standard germination test. Percent germination was near or above that of the standard germination test for at least one $\mathrm{pH}$ level for five of the eight species germinated on filter paper (Table 1).

However, germination results on peatlite medium were not similar to seed laboratory results. Only three species approached the percent germination from the standard germination test. Across the $\mathrm{pH}$ range evaluated, germination percentage in peatlite medium was lower than that on filter paper. This trend is consistent with results with Luctuca sativa (Nichols and Heydecker, 1968)

Since most seeds are germinated in a growing medium, this difference between percent germination from standard germination tests and that from a peatlite medium suggests the following: first, the information reported from standard germination tests cannot be used to predict the relative establishment value of different seed lots in a growing medium; second, predictors for seed germination in a growing medium need to be established.

For each species, high germination percentage was achieved within a range of $\mathrm{pH}$ values. When placed on saturated filter paper, most species germinated best at $\mathrm{pH} 5.5$ to 7.5 . The $\mathrm{pH}$ range was less predictable for high germination peat medium. The $\mathrm{pH}$ range for some species was narrower. No optimum $\mathrm{pH}$ for each species was evident.

\section{Literature Cited}

Bailey, D.A. and P.A. Hammer. 1986. Growth and nutritional status of petunia and tomato seedlings with acidified irrigation water. HortScience 21(3):423-425.

Carlson, W .H. and E.M. Rowley. 1980. Bedding plants, p. 447-522. In: R.A. Larson (cd.). Introduction to floriculture. Academic, New York.

Chan, C.T. 1937. Study of the relation of different $\mathrm{pH}$ values of nutrient solution and tree seed germination. J. Agr. Assn. (China) 158:21-47.

Hunter, E. A., C.A. Glasbey, and R.E.L. Naylor. 1984. The analysis of data from germination tests. J. Agr. Sci., Carob. 102:207-213.

Jansen, L.L. and E.H. Cronin. 1953. Halogeton on trial. Farm \& Home Sci. (Utah) 14:38-39.

Koranski, D. 1985. Plug production in the bedding plant industry. Part II. Bedding Plant Intl. News. 16(10):7-9.

Malhotra, R.C. 1930. A new method of germination and the influence of hydrogen-ion con- 
centration on the germination and growth of Helianthus annuus and Lycopersicum [sic] esculentum. J. Indian Bot. Soc. 9:218-239.

Nichols, M.A. and W. Heydecker. 1968. Two approaches to the study of germination data. Proc. Intl. Seed Test Assn. 33(3):531-540.
Peel, L.W. 1949. Germination and development of heather and hydrogen-ion concentration of the medium. Nature (London) 163:647-648.

Promsy, G. 1911. Influence of acids on germination. Academic des Sciences (Paris) 152:450452 .
Salter, R.M. and T.C. McIlvaine. 1920. Effect of reaction of solution on germination of seeds and on growth of seedlings. J. Agr. Res. 19:73-95.

Schmidt, W. 1927. Reaktionsempfindlichkeit von Keimlingen. Forstarchiv 3(6):81-82.

\section{Influence of Photoperiod on Liatris spicata Generative Shoot Growth}

\author{
Ignacio Espinosa'and Will Healy ${ }^{2}$ \\ Department of Horticulture, University of Maryland, College Park, \\ MD 20742
}

Additional index words. cut flower, pot plant, stem elongation, short days, facultative long-day plant

Abstract. One-year-old corms of Liatris spicata Willd. produced from seed and 2-yearold corms from division of previously forced corms were placed under 8 hours of natural daylight plus 0,4 , 6 , or 8 hours of incandescent $\left(5 \mu \mathrm{mol} \cdot \mathrm{s}^{-1} \cdot \mathrm{m}^{-2}\right)$ day continuation to equal 8-, 12-, or 16-hour photoperiods. Plants were grown under these photoperiods during the first 35 days after shoot emergence (initial) and then were grown under a second photoperiod of $8,12,14$, or 16 hours until harvest (final). The combination of initial and final photoperiod treatments resulted in a total of 16 photoperiod combinations. Two-year-old corms flowered 10 days earlier than l-year-old corms, but l-year-old corms produced twice as many vegetative shoots and $15 \%$ more flowering shoots than the 2-year-old corms. Long initial photoperiod (14 or 16 hours) treatments . (LD) reduced-the days to flower by 8 days and increased flower shoot elongation by $20 \mathrm{~cm}$, compared with initial short days (8 or 12 hours, SD). However, initial LD treatments decreased the number of flowering shoots by $50 \%$, compared to initial SD treatments. An initial SD followed by a final LD did not decrease the number of flowering shoots, yet promoted greater stem elongation $(92 \mathrm{~cm})$ than continuous LD $(83 \mathrm{~cm})$.

The effect of photoperiod on Liatris has been studied by various authors. Flowering in L. spicata was promoted by long days (LD) (Durieux, 1978), while L. graminifolia was described as a short-day (SD) plant (Allard and Garner, 1940). A LD treatment was not obligatory for flower initiation, but stem elongation (Durieux, 1978; Kofranek, 1980; Koziol et al., 1981; Zieslin and Geller, 1983) and stem rigidity (Zieslin and Geller, 1983) were promoted by LD.

Zieslin and Geller (1983) found that an 8$\mathrm{hr}$ photoperiod doubled the number of flower stems harvested compared to the 16-hr treatment. An 8-hr photoperiod for 3 weeks, followed by one of $16 \mathrm{hr}$ until anthesis, did not reduce the number of flowering stems. This result was in contrast to reports with gladiolus, where SD caused a low flowering percentage (Halevy, 1985; Shillo and Halevy, 1976). Long-day treatments provided by incandescent lamps promoted winter flowering of gladiolus in greenhouses (Halevy, 1985)

Received for publication 13 Aug. 1987. Scientific Article no. A-5011 of the Maryland Agricultural Experiment Station. The cost of publishing this paper was defrayed in part by the payment of page charges. Under postal regulations, this paper therefore must be hereby marked advertisement solely to indicate this fact.

'Graduate Student.

${ }^{2}$ Assistant Professor. and in fields in Israel (Shillo et al., 1981) and Australia (Mckay et al., 1982). In California, Kofranek (1980) recommended that Liatris be grown under LD (2200 to 0200 HR) to promote stem elongation. This rec-

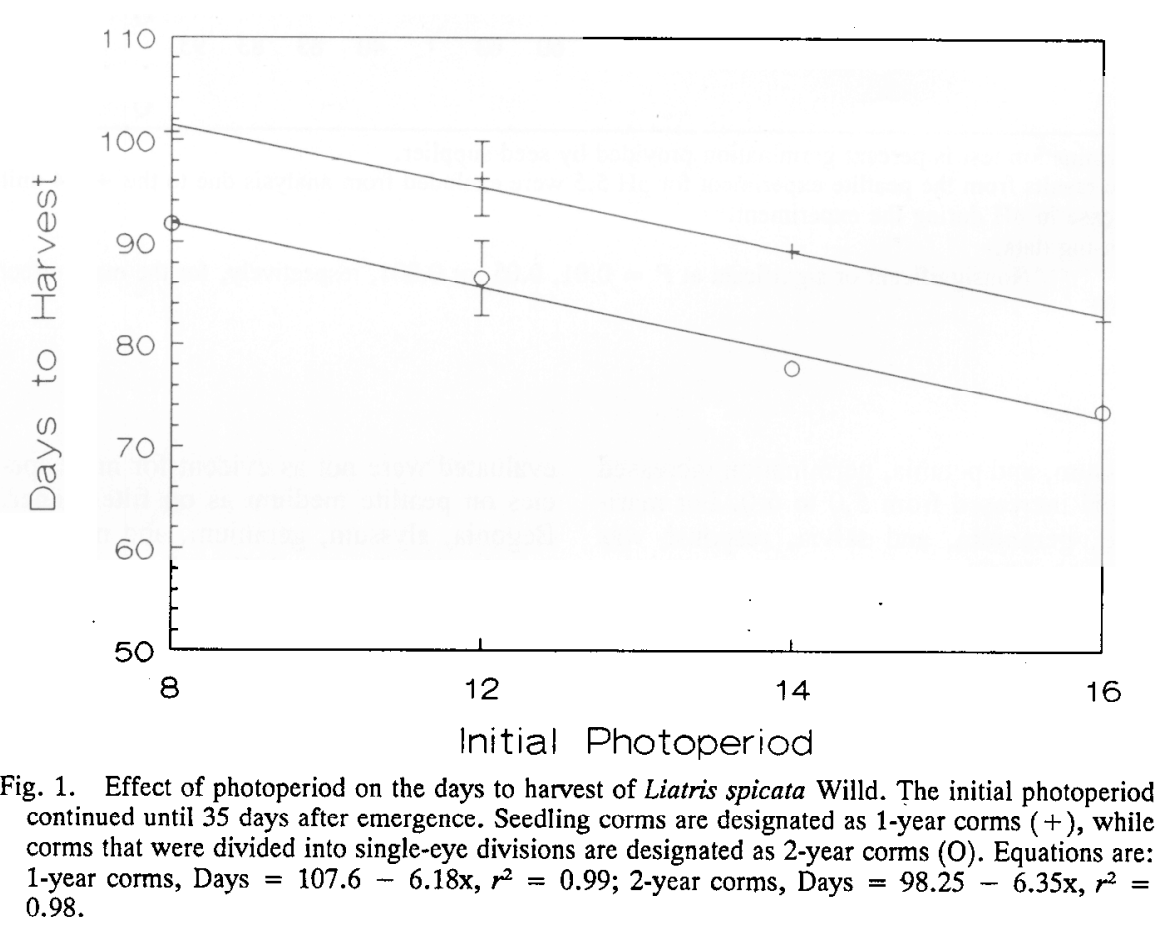

Fig. 1. Effect of photoperiod on the days to harvest of Liatris spicata Willd. The initial photoperiod continued until 35 days after emergence. Seedling corms are designated as 1-year corms (+), while corms that were divided into single-eye divisions are designated as 2-year corms $(\mathrm{O})$. Equations are: 1 -year corms, Days $=107.6-6.18 \mathrm{x}, r^{2}=0.99 ; 2$-year corms, Days $=98.25-6.35 \mathrm{x}, r^{2}=$ 0.98. moved to an 8-, 12-, 14-, or 16-hr photoperiod until harvest. This combination resulted in a total of 16 photoperiods. Each photoperiod treatment had 12 plants, each of 1- and 2-year-old corms. The experiment was ommendation seems to have been intuitive, as no data were presented to support this recommendation. Once the stem was elongated, flowering occurred more rapidly under natural winter SD conditions than under LD (Shillo and Halevy, 1976).

The objective of our research was to study the effect of photoperiod treatment and corm age during two developmental stages on generative shoot development of Liatris spicata.

One- and 2-year-old corms (2.5- to 3.5$\mathrm{cm}$ diameter) were used. One-year-old corms, produced in the Netherlands from seedlings, were cold-treated at $2 \mathrm{C}$ for 8 weeks, then stored at $-2 \mathrm{C}$ until used. The 2-year-old corms were obtained by division of corms forced in Maryland the first year, then coldtreated to break dormancy (12 weeks at $2.5 \mathrm{C}$ ). These corms were divided into single-bud corm divisions of uniform size. The corms were planted 24 Jan., one per 1.75-liter pot, and grown in a glasshouse at $18 \mathrm{C}$ night air temperature. Plants were fertilized weekly with $20 \mathrm{~N}-9 \mathrm{P}-16.6 \mathrm{~K}$ at $200 \mathrm{mg} / \mathrm{liter}$.

After emergence, photoperiod treatments of an 8-hr natural day plus a 0-, 4-, 6-, or 8 -hr day continuation with incandescent irradiance $\left(5 \mu \mathrm{mol} \cdot \mathrm{s}^{-1} \cdot \mathrm{m}^{-2}\right)$ to equal 8 -, 12-, 14-, or 16-hr photoperiods were applied for 35 days. (initial). The plants were then 